Journal of Social Sciences 7 (4): 579-585, 2011

ISSN 1549-3652

(C) 2011 Science Publications

\title{
An Appraisal of Foreign Exchange Resources Generation and Management
}

\author{
Olorunfemi Sola and Adebayo A. Fatukasi \\ Department of Economics, Faculty of Social and Management Sciences, \\ Adekunle Ajasin University, Akungba Akoko, Ondo State, Nigeria
}

\begin{abstract}
Problem statement: The study reviewed and appraised foreign exchange resources generation during and after SAP, it also identified the problem area of foreign exchange resources generation and management. Approach: Secondary data from CBN statistical bulletin were analyzed using descriptive and comparative analysis. Results: Result shows that the contribution of non-oil export to total export was as low as 1.5, 4.87, 3.07, 2.46, 1.66 and $2.82 \%$ for 2001-2006 compared with oil export which was high for the periods and that this was caused by unstable exchange rate. The result revealed increase in the level off investment for the period. Conclusion: In conclusion, effort should be aimed at blocking areas of reserve leakages. Other sources of generating foreign exchange should be pursued.
\end{abstract}

Key words: Foreign exchange generation, oil export, non-oil export, external reserves, exchange rate, foreign exchange resources

\section{INTRODUCTION}

The importance of foreign exchange resources is a product of the low level of economic development of the country, which results in a largely open economy dependent on the industrial advanced countries, not only for its technology and goods, but, also for its basic consumer products (including food), raw materials and even highly skilled industrial personnel. This dependence involves transactions which are often paid in foreign exchange. The more foreign exchange resources the country possesses, the more it will be able to provide the wherewithal necessary to keep its industries running, make needed products available on its shelves and make it feasible to acquire new technology and management skills (IMF, 2004). In a sense, therefore, foreign exchange may, in fact largely determine the level of general economic activity in the country hence growth in GDP. It thus constitutes a key resource, the efficient management of which is indispensable to accelerating the pace of our economic development. The current economic slump, with all the attendant dislocations such as labour retrenchment which further worse the level of unemployment call for attention and solution. In Nigeria, CBN shows that from a low level of 41452.4 naira in 1986, our foreign debt rose steeply to 3097383.9, 3176291.0, 39328884.8, 4478329.3 and 4890269.6 million naira in 2000, 2001, 2002, 2003 and 2004 respectively but fell to $4514617 \mathrm{~m}$ in 2006 (Table 1). A larger part of this debt/loan to Nigeria is not properly channeled. Also, part of the foreign exchange generated from other sources in Nigeria goes to service debt. The opportunity cost of such high proportion of foreign exchange earnings going to service debt is the current consumption forgone, with the attendant multiplier implications.

A prudent management of foreign exchange resources is thus a good background for the attainment of economic development in Nigeria. The argument is that the present foreign exchange resources generated is structurally defective because of the imbalances in the factors such as the foreign currency receipt from the exports of goods, investment, loan of all designations as well as grant or aids which represent unilateral transfer. For example, the continuing disappearance of the traditional exports and the non-existence of manufactured exports meant absolute reliance on oil for foreign exchange earnings. The dependence on this narrow and inelastic export base is fraught with danger. It exposes the country to the vagaries and uncertainties of world oil market that has become increasingly erratic since the 1980-83 worldwide recession.

It is against this background that a research into the foreign exchange resources generation is important.

Corresponding Author: Olorunfemi Sola, Department of Economics, Faculty of Social and Management Sciences, Adekunle Ajasin University, Akungba Akoko, Ondo State, Nigeria 
J. Social Sci., 7 (4): 579-585, 2011

Table 1: Some important economic indicators

\begin{tabular}{|c|c|c|c|c|c|c|}
\hline Year & $\begin{array}{l}\text { Export } \\
\text { ( } \# \text { million) }\end{array}$ & $\begin{array}{l}\text { Import } \\
\text { (A million) }\end{array}$ & 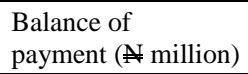 & $\begin{array}{l}\text { External reserve } \\
\text { ( } A \text { million) }\end{array}$ & $\begin{array}{l}\text { Exchange rate } \\
(\mathrm{A} / \$ 1.00)\end{array}$ & $\begin{array}{l}\text { Inflation } \\
\text { rate }(\%)\end{array}$ \\
\hline 1986 & 8920.6 & 5983.6 & -784.3 & 2836.60 & 2.0206 & 5.4 \\
\hline 1987 & 30360.6 & 17861.7 & 159.2 & 7504.59 & 4.0179 & 10.2 \\
\hline 1988 & 31192.8 & 21445.7 & -2294.1 & 5229.10 & 4.5367 & 38.3 \\
\hline 1989 & 57971.2 & 30860.2 & 8727.8 & 3047.62 & 7.3916 & 40.9 \\
\hline 1990 & 109886.1 & 45717.9 & 18498.2 & 4541.45 & 8.0378 & 7.5 \\
\hline 1991 & 121535.4 & 89488.2 & 5959.6 & 4149.30 & 9.9095 & 13.0 \\
\hline 1992 & 205611.7 & 143151.2 & -65271.8 & 1554.61 & 17.2984 & 44.5 \\
\hline 1993 & 218770.1 & 165629.4 & 13615.9 & 1554.61 & 22.0511 & 57.0 \\
\hline 1994 & 206059.2 & 162788.8 & -42623.3 & 9009.11 & 21.8861 & 57.0 \\
\hline 1995 & 950661.4 & 755127.7 & -195316.3 & 9009.11 & 21.8861 & 72.8 \\
\hline 1996 & 1309543.4 & 562626.6 & -53152.0 & 3403.91 & 21.8861 & 29.3 \\
\hline 1997 & 1241662.7 & 845716.6 & 1076.3 & 7222.22 & 21.8861 & 8.5 \\
\hline 1998 & 751856.7 & 837418.7 & -220675.1 & 7107.50 & 21.8861 & 10.0 \\
\hline 1999 & 1188969.8 & 862515.7 & -326634.3 & 5440.71 & 92.6934 & 6.6 \\
\hline 2000 & 1945723.3 & 985022.4 & 314139.2 & 9386.10 & 102.1052 & 6.9 \\
\hline 2001 & 1867953.9 & 1358180.3 & 24738.7 & 10266.56 & 111.9433 & 18.9 \\
\hline 2002 & 1744177.7 & 1512695.3 & -563483.9 & 7681.12 & 120.9702 & 12.9 \\
\hline 2003 & 3087886.4 & 2080235.3 & -162298.4 & 7467.80 & 129.3565 & 14.0 \\
\hline 2004 & 4602781.5 & 1987045.3 & 1124157.2 & 16955.02 & 133.5004 & 15.0 \\
\hline 2005 & 6372052.4 & 2479322.5 & 1362253.9 & 28279.10 & 132.1470 & 17.9 \\
\hline 2006 & 5752747.7 & 2528086.0 & 1772650.9 & 42298.11 & 128.6516 & 8.2 \\
\hline
\end{tabular}

The much available work centered on the instruments used to manage foreign exchange in Nigeria while none or few work centered on foreign exchange resources generation in Nigeria which suppose to be an important aspect of foreign exchange resources management. It is noted that none of the available work tried to look at the foreign exchange resources generation during SAP and after SAP periods. The main purpose of this research project is to appraise foreign exchange resources generation in Nigeria during these two important periods. However for the purpose of analysis, we state the specific objectives as follows:

- To review and appraise foreign exchange resources generation in Nigeria during and after SAP

- To identify the problem areas of foreign exchange resources generation and management in Nigeria

Literature review: As it was rightly observed by Ali et al. (2008) that management of foreign exchange resources requires two activities: the generation of foreign exchange through export and the allocation of resources so generated to produce the optimum level of development. In addition to this, foreign exchange can further be generated through loan and investment. According to (Al-Halalmeh and Sayah, 2010) the balance between the exports and imports of a country affect the level of foreign exchange. Foreign exchange can be accumulated if the visible exports of a country are more than the visible imports. The difference (surplus or deficit) results from either increased volume of exports or imports or changes in the prices of exports or imports or changes in both volume and prices.
Al-Halalmeh and Sayah (2010) further said that the balance in the services account or what is often described as invisible account are the principal means of earning foreign exchange. But a country may be said to be importing foreign exchange or capital if it fails to acquire foreign exchange through the process of exports of goods or services. In that case it could borrow from other countries or encourage the citizens of other countries to invest in the country. To ensure adequate level of foreign reserves, all sources of foreign exchange must be properly managed. The question of the adequacy of international reserves has been discussed widely in the literature. In the recent times there has been an increasing interest in the determination of the specific level of international reserves which would be "adequate" in term of some criterion expressing the need of reserves. According to (Umar and Soliu, 2008), optimal reserves are the level of reserves which are sufficient to finance balance of payment disequilibrium occurring in a planning period subject to the opportunity cost of keeping the reserves. And one of the importances of reserve is to serve as a buffer stock accommodating fluctuations in external transaction; the expectation is that the desire stock of reserve is positively related to the variability of external net receipt. Keynessian models of the adjustment mechanism which are characterized by the adjustment of the output suggest that for a given reduction in export earning, the cost of not having reserve and the demand for reserve is inversely proportional to the relative size of the foreign trade sector. Explaining further CBN Omolayo Gurbuz and Aybars (2010); Gan et al. (2004) and Yazdani and Shaari (2009) said that 
since the keynessian revolution, there has been a movement from the automatic approach to the balance of payments described above to the policy problem approach which accepts the facts of continuing disequilibrium and then goes on to look into the policy objectives that must be adopted. Abstracting from autonomous capital movements, the new policy approach (called the absorption approach defines Balance of payment (B) as the difference between total output (y) and total domestic Expenditure (E) i.e., B = $\mathrm{Y}$-E whereas the traditional approach views balance of payments as the difference between Receipt (RF) and Payments to Foreigners (PF), i.e., $B=R F-P F$.

A balance of payments deficit (on the absorption approach) entails an excess of expenditure over output or income. To correct the deficit and hence disallow a fall in foreign exchange, expenditure and income must be brought to equality.

Any country who wants to manage its foreign exchange resources well should adopt for her acceptable criteria to measure the adequacy of the foreign exchange resources. Nonetheless, since the importance of foreign exchange is different from country to country, there has not emerged a generally acceptable method of determining foreign exchange adequacy. Foreign exchange resources will depend on, among other factors, the motive for holding the resources as well as the rate of their inflow and disbursement. At a rather theoretical level, adequacy can be related to some macro-economic variables such as the money supply, national income and trade balance. At a practical level, reserve adequacy is measured by specifying a given level of reserve that is sufficient to meet the need of an economy over a given period of time. This is the basis of reserve/import ratio which emphasis the transaction motive for holding reserve by specifying the minimum reserve requirement of a country that would meet her import demand over some given period of time.

According to Gan et al. (2004), reserve adequacy was important to ensure that the foreign exchange reserve was maintained at levels consistent with current and future international commitments.

From the foregoing, the importace of foreign exchange resources to development is not in doubt. Many studies in Nigeria on foreign exchange such as, Adamgbe (2006) and Umar and Soliu (2008) centered their studies on the instruments used to manage foreign exchange in Nigeria while none or few work centered on foreign exchange resources generation in Nigeria which suppose to be an important aspect of foreign exchange resources management. This is the major gap that this study intends to cover.

\section{METERIALS AND METHODS}

The type of data used was secondary data mainly from publication of Central Bank of Nigeria, such as CBN Economic and Financial Review and CBN Statistical Bulletin.

The type of analytical technique that was employed in this research study was descriptive and comparative analysis. In presenting the relevant data, we made use of tables and percentages, since they were available, it helped in analyzing the study and the result very well so that we would have clear understanding of the research and also it made the usage of these tables and figure to be explained in a clear way.

\section{RESULTS AND DISCUSSION}

Appraisal of foreign exchange resources generation and management under sap and after sap periods: The serious economic problems facing the Nigeria economy at the close of 1985 led to the adoption of a programme that had far reaching economic consequences in the 1986 budget. During the second half of the year, the programme was reviewed in close collaboration with the IMF and the World Bank into a more comprehensive Structural Adjustment Programme (SAP) on 1st July 1986. Economic policy proposal, which were a clear departure from previous policy strategies were introduced. Though, it was agreed that the control measure did, to some extent, help in reducing foreign exchange expenditure, their cost to the economy was taken to be too high.

As a result, the 1986 budget sought to de-emphasis controls and adopted policy measures aimed at increasing the resource base of the economy. To achieve this goal, the 1986 budget had the following three important measures:

- The first set of measure was contained in the Export (Incentives and Miscellaneous Provision) Decree of 1986 with the aim of enhancement of the country's level of foreign exchange earnings from non-oil sectors which would also greatly reduce the dependence on the oil sector as the main source of foreign exchange. In this same decree, there was a currency retention scheme under which exporters of non-oil goods were allowed to retain $25 \%$ (later increased to $100 \%$ under SAP) of their export proceeds as an incentive to encourage them to produce more for export

- The second was the introduction of the Domiciliary Account Scheme which allowed individuals and corporate bodies resident in Nigeria to have or 


\section{J. Social Sci., 7 (4): 579-585, 2011}

operate foreign currency accounts with banks in Nigeria. The reasons of the measure were to discourage the outflow of foreign exchange by residents and decrease the demand pressure on official foreign exchange resources

- The 1986 budget determined to establish the Second tier Foreign Exchange Market (SFEM) later in the year as a means of having a more rational determination of the naira exchange rate and consequently a more efficient allocation of foreign exchange resources, economic deregulation as against economic control was the philosophy behind SAP

For appropriate foreign exchange management, some instruments were designed and backed up by appropriate measure. The instruments include the operation of strict foreign exchange budget control, pegging debt service payments and evolving a viable exchange rate of the naira. Government authority also uses monetary and fiscal policies to support these tools from time to time.

From the foregoing and for proper evaluating the effectiveness of the foreign exchange management strategies adopted since 1986, we intend to identify the achievement of the new system, as well as the outstanding problems. It is clear that there has been a shift in emphasis towards importation of machinery/equipment and raw materials for productive sector as against the high importation of consumer goods (food) in the pre-SAP period. For instance before SAP the total value of food and live animal imported in 1985 was $1199 \mathrm{~m}$ but this dropped to $801.9 \mathrm{~m}$ in 1986 and increased sluggishly to $3474.1 \mathrm{~m}$ in 1990 . While the value of machinery and equipment imported increased from $2414.4 \mathrm{~m}$ in $1985-8515.8 \mathrm{~m}$ in 1990 . This scenario is painted in Fig. 1 as the importation of machinery/equipment (capital) goods used by industries continues to increase as against the importation of food. The importation of food was not noticeable from 1986 up till 1990 as shown in Fig. 1. This was against what obtained before the introduction of SAP.

Based on the available data and information, there has been expanding and diversifying non-oil exports because before SAP the non-oil export was 554.4, 342.8, 203.2, 301.3 and $247.7 \mathrm{~m}$ for the periods $1980-1985$ respectively but this rose to 552.1, 215.2, 2757.4, 2954.4 and 3259.6m during SAP i.e., between 1986-1990.

There has been an improvement in the export promotion drive consequent upon which we recorded an improved overall balance of payment. Despite this, the exchange rate of naira was said to be moving to its equilibrium level, that is, towards a more appropriate level since SAP.

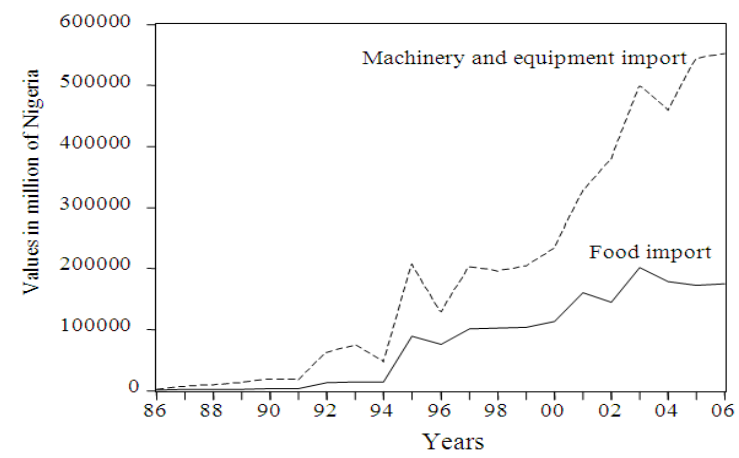

Fig.1: Food and machinery imported to Nigeria in 1986-2006

While the foreign exchange management strategies since 1986 have brought some economic benefits, some problems have emerged and in most cases reflect symptoms of the economy's problems. Among these problems are; the instability problem of the naira exchange rate since SAP. For instance, in Table 1 the exchange rate was as low as 2.0206 in 1986 but this rose to 128.6516 at the close of 2006 . The instability of the market rates was major concern to the authorities. Frequent institutional adjustments added to the instability since the authorities all along wanted to achieve the objective of enhanced private foreign exchange earnings in view of the instability of the official component. Study by FSDH (2009) reveals that there was slight appreciation of the value of Naira which appreciated by $8.07,8.03$ and $7.55 \%$ in relation to the value of the USS Dollar in the inter-bank market, official market and the parallel market respectively in 2007. The appreciation in the value of Naira in 2007 was on account of escalating price of crude oil in the international market.

The fundamental factors of the unstable naira exchange rate and the weakness of the naira is associated with the fragile export base and the high import dependence of the economy on oil still continue to count for more percentage of the total export earning while the prices of non-oil exports declined. In Table 1 , export which was just 8920.6, 30360.6 and 31192.8 in 1986, 1987 and 1988 rose to $1867953.9,1744177.7$, $3087886.4,4602781.5,6372052.4$ and 5752747.7 for 2001, 2002, 2003, 2004, 2005 and 2006 respectively. The export of non-oil export continues to be low due to the continual dependence of Nigeria on oil. This reflected in Fig. 2 as the oil export continues to increase. From Table 3, it is noted that the total amount of non-oil export to total export was just 28018.6, 94731.8, 94736.4, 113309.4, 105955.8 and 133594.9 for 2001, 2002, 2003, 2004 and 2005 respectively and this represent 1.5, 4.87, $3.02,2.46,1.66$ and $2.32 \%$ for the periods respectively. 
J. Social Sci., 7 (4): 579-585, 2011

Table 2: Inflow of foreign exchange 2001-2006 ( $\mathrm{N}$ million)

\begin{tabular}{|c|c|c|c|c|c|c|}
\hline & 2001 & 2002 & 2003 & 2004 & 2005 & 2006 \\
\hline Merchandise & 1867954.0 & 1944177.7 & 3087886.6 & 4602781.6 & 6392054.4 & 5752747.8 \\
\hline (a) Oil & 1839935.4 & 1849445.9 & 2993110.0 & 4489472.2 & 6286098.6 & 5619152.9 \\
\hline (b) Nonoil & 28018.6 & 94731.8 & 94776.4 & 113309.4 & 105955.8 & 133594.9 \\
\hline Capital & 00.0 & 6547.0 & 2621.1 & 47215.0 & 2956.7 & 4528.6 \\
\hline Services & -332293.9 & -288176.8 & -288698.8 & -349150.3 & -210236.9 & 44237.6 \\
\hline Total & 1535660.1 & 1662547.9 & 2801808.9 & 4300846.3 & 6184774.2 & 580151.4 \\
\hline
\end{tabular}

Table 3: Investment, loan and GDP growth in Nigeria 1986 - 2006

\begin{tabular}{|c|c|c|c|c|c|c|}
\hline Year & Investment & Loan/debt & $\begin{array}{l}\text { GDP } \\
\text { growth index }(\%)\end{array}$ & $\begin{array}{l}\text { Investment } \\
\text { growth index }(\%)\end{array}$ & $\begin{array}{l}\text { Loan/debt } \\
(\%)\end{array}$ & GDP growth index \\
\hline 1986 & 2813088.0 & 41452.4 & 257784.5 & 100.0 & 100.0 & 100.0 \\
\hline 1987 & 3125223.0 & 100789.1 & 255997.0 & 111.0 & 243.1 & 99.3 \\
\hline 1988 & 3639888.0 & 133956.3 & 275409.6 & 129.4 & 323.2 & 106.8 \\
\hline 1989 & 5436637.0 & 240393.7 & 295090.8 & 193.3 & 579.9 & 114.5 \\
\hline 1990 & 7188636.0 & 298614.4 & 328606.1 & 255.5 & 720.4 & 127.5 \\
\hline 1991 & 9121579.0 & 328453.8 & 328644.5 & 324.3 & 792.4 & 127.5 \\
\hline 1992 & 10184601.0 & 544264.1 & 337288.6 & 362.0 & 1312.9 & 130.8 \\
\hline 1993 & 13416946.0 & 633144.4 & 342540.5 & 476.9 & 1527.4 & 132.9 \\
\hline 1994 & 13086064.0 & 648813.0 & 345228.5 & 465.2 & 1565.2 & 133.9 \\
\hline 1995 & 30776987.0 & 716865.6 & 352646.2 & 1094.0 & 1729.4 & 136.8 \\
\hline 1996 & 36346604.0 & 617320.0 & 367218.1 & 1292.0 & 1489.2 & 142.5 \\
\hline 1997 & 35237816.0 & 595931.9 & 377830.8 & 1252.6 & 1437.6 & 146.6 \\
\hline 1998 & 39156233.0 & 633017.0 & 388468.1 & 1391.9 & 1527.1 & 150.7 \\
\hline 1999 & 41455540.0 & 2577374.4 & 393107.2 & 1473.7 & 6217.7 & 152.5 \\
\hline 2000 & 50253869.0 & 3097383.9 & 412332.0 & 1786.4 & 7472.1 & 159.9 \\
\hline 2001 & 44876484.4 & 3176291.0 & 431783.2 & 1595.3 & 7662.5 & 167.5 \\
\hline 2002 & 56377047.4 & 3932884.8 & 451785.7 & 2004.1 & 9487.7 & 175.3 \\
\hline 2003 & 65151070.0 & 4478329.3 & 495007.2 & 2315.9 & 10803.5 & 192.0 \\
\hline 2004 & 77648461.2 & 4890269.6 & 527576.0 & 2760.3 & 11797.3 & 204.7 \\
\hline 2005 & 101133215.5 & 2695072.2 & - & 3595.1 & 7152.9 & - \\
\hline 2006 & 125508669.6 & 451461.7 & 562043.7 & 4461.6 & 1089.1 & 218.0 \\
\hline
\end{tabular}

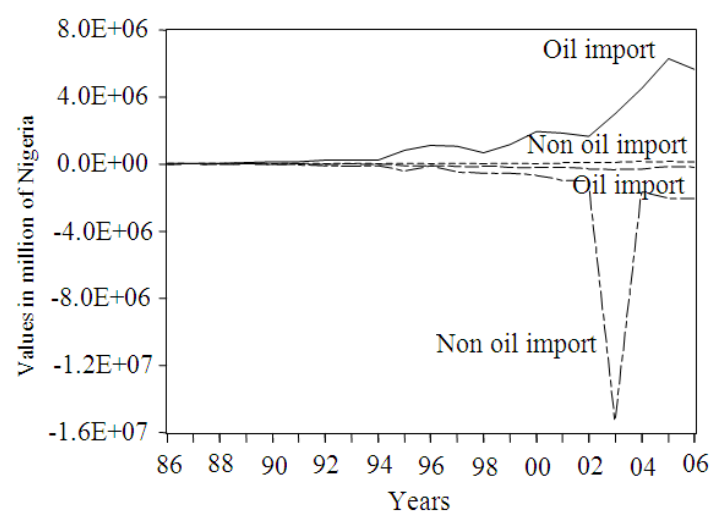

Fig. 2: The trend of export and import for oil and non oil for Nigeria between1986-2006

Table 2 shows the inflow of foreign exchange during the period 2001-2006. The revenue stood at 1535660.1, $1662547.9, \quad 2801808.9, \quad 4300846.3 \quad 6184774.2$ and 580151.4 million naira for the year 2001-2006 respectively.

Table 3 shows the growth rates in other sources of generating foreign exchange. And these include investment and loan/debts. Although Table 3 shows that there was continual increase in the growth index for both investment and loan/debt and even in total export in Table 1, this is not felt by the economy of Nigeria as the economy still continued to depend on oil export.

The external reserve according to the FSDH (2009), Nigeria's external reserves figure as at January 2008 stood at \$54.22Billion. The level of reserve was estimated at \$52Billion as at December, 2007. At this level of reserve in December, 2007, the growth rate over the preceding year's figure of $\$ 45.01$ billion was $15.53 \%$.

The problems of foreign exchange management in Nigeria: The government over the years or perhaps since 1986 used different measures to manage the foreign exchange of the country. But it is disheartened to see that the various measures effected in trying to judiciously manage the foreign exchange resources of Nigeria have yielded less than satisfactory results. This could be because of the many lapses in implementing the measures or because of not being fully committed to the course for which the measures were designed and put in force, both government and its enforcement agencies always performed below expectation. There has been problem in foreign exchange management in Nigeria because less 


\section{J. Social Sci., 7 (4): 579-585, 2011}

attention has been given to foreign exchange lost as a result of smuggling, illegal transaction in foreign exchange and outright corruption. This is not to say that the amount lost to the nation through these various illegal economic activities and malpractices is not substantial enough to deserve attention. In fact such amount has been estimated to worth several billions of naira per annum. The problem is that there are no reliable sources where information is properly quantified or documented. As from the inception of SAP, there have been problem of instability of exchange rate, this is reflected in Table 1 and with this the naira is highly undervalued. The adverse effects of exchange rate mechanism are enormous. For instance, due to the continuous depreciation of the naira, exchange rate has led to the rise in cost of production hence leading to the overall rise in prices.

From Table 1, we observe that, the exchange rate is in shambles as the values of naira against dollar continue to fall, hence foreign exchange resources management has been in a mess.

Another foreign exchange generation and management problem stems mostly from the fact that our industries rely entirely on imported raw materials whereas the raw materials are found in Nigeria. It is likely that companies, especially the government owned companies import such materials in order to have the chance of transferring foreign exchange for private purposes. And there are many of such cases where local materials can be used but are being imported. Moreover, substantial parts of foreign exchange earnings are used to purchase consumer goods abroad. This is reflected in Fig. 1, although the importation of consumer goods is not as high as the importation of machinery but was still increasing between 1986-2006.

There is the problem of discrepancies between actual and optimal levels of reserves. Actual reserves are the observed stock of reserves held by a country at a period of time while optimal reserves are the level of reserves that are enough to finance balance of payment problems of a country. These discrepancies have implications on the demand function for foreign reserves and can cause changes in government reserve policies and hence create problem for the government effort at managing foreign exchange resources.

Another problem is an increase in the domestic prices thus leading to inflation. In Table 1 the inflation rate seems to remain at two digits throughout the periods considered in the research work. Furthermore, the prevalence of smuggling of Nigerian currency (for conversion in the parallel market) and commodity across the border led to loss of government revenue. Another major defect of the Nigerian economy is the monoculture nature of the economy, that is, heavy dependency on the export of one major commodity i.e., oil. This makes the economy liable to fluctuations, depending upon the performance of the world oil market. From Table 3, it is seen that the inflow of foreign exchange from oil sector reached its peak in the year 1982 when it stood at $\$ 22,932.6 \mathrm{~m}$. But it is pathetic to notice that since then it has continued to follow a falling trend to the extent that it dropped to $\$ 7,437.1 \mathrm{~m}$ in 1990 . This has virtually contributed to the discrepancy between optimal and actual reserves.

\section{CONCLUSION}

To increase foreign exchange earnings, effort should be made to increase the consumption of made in Nigeria goods, including usage of raw material that can be sourced locally by Nigerian industries, that is, local industries must look inward for their raw material.

There should be an active monitoring and management of debts that involve the roll-over and rescheduling of short-term foreign trade areas into medium and long-term debts in order to conserve the minimal available foreign exchange.

Foreign exchange allocation should not be greater than the budgeted estimation. Government should make efforts to streamline spending with revenue earnings and make payment on current basis. This should be continued until the country's economy returns to normal. Thereafter, foreign exchange spending should be tailored to available sources.

Demand for foreign exchange should be reduced by developing better social services and by reviewing our industrialization policy. Our industrialization policy should be reviewed with a view to shifting emphasis from market-base industries. The latter will depend more on local raw materials, rather than imports as in the case of the former.

Infrastructural facilities should be developed in the rural areas where farming is mainly carried out. Farmers should be encouraged to produce more through the implementation of a price-guarantee-scheme for their products. A successful implementation of an efficient agricultural development programmed should go a long way to reduce the current drain on the nation's foreign exchange resources caused by food importation.

Furthermore, the development of export must form an important objective of government policy, particularly given the continuing depreciation in the value of the Naira. A strong, virile export base is needed to enable the naira regain its international stature. This can be achieved only when foreign exchange is sufficient to cushion fluctuations and pressures on the external value of naira. 
Inflationary pressures being experienced in Nigeria can be reduced if we export and earn more foreign exchange and thereafter build up the level of foreign exchange reserve. If adequate foreign exchange is generated and managed well it will lead to build up of adequate foreign exchange reserve which according to IMF (2004) will provide the following advantages:

- Support and maintain confidence in the policies for monetary and exchange rate management, including the capacity to intervene in support of the national or union currency

- Limit external vulnerability by maintaining foreign currency liquidity to absorb shocks during times of crises or when access to borrowing is curtailed and in doing so

- Provide a level of confidence to markets that a country can meet its external obligations

- Demonstrate the backing of domestic currency by external assets

- Assist the government in meeting its foreign exchange needs and external debt obligations

- Maintain a reserve for national disasters or emergencies

To achieve good foreign exchange resources management, based on the above findings, efforts should be aimed at blocking areas of reserve leakages in periods when reserve are below the optimum by the use of contranctionary monetary policy and minimizing the opportunity cost of reserves/when reserves are above the optimum. Efforts should be directed to the sources of the country's foreign exchange other than oil export. It could be in form of long-run measure to increase agricultural products and manufactured goods. Efforts should be geared towards moving resources gradually from consumption to investment in industrial goods, from import to export trade and from social to purely economic activities.

To be able to achieve the above, Nigeria needs good leaders who must be focused and have sincere attitude. These leaders must enjoy the confidence of those who are working with them in terms of transparency. The government must have clear conscience about her direction concerning how best to manage foreign exchange.

\section{REFERENCES}

Adamgbe, E.T., 2006. Exchange rate management under the wholesale das in nigeria: policy implications. West Afri. J. Monetary Econ. Intergrat., 6: 5-7.

Al-Halalmeh, M.I. and A.M. Sayah, 2010. Impact of foreign direct investment on shares market value in amman exchange market. Am. J. Econ. Bus. Admin., $\quad 2$ : $\quad 35-38 . \quad$ DOI: 10.3844/ajebasp.2010.35.38

Ali, A., T. Shukui, S. Selvarathnam, X. Xiaolin and A. Saboor, 2008. Political stability and balance of payment: An empirical study in Asia. Am. J. Applied Sci., 5: 11 49-11 57. DOI: 10.3844/oyassp. 2008. 1149:1157

FSDH, 2009. Nigeria economy of financial market (Review and Outlook).

Gan, C., S. Treepongkaruna and H. Hue, 2004. Revisiting the unit root hypothesis and structural break: Asia and emerging economies foreign exchange markets. Am. J. Appplied Sci., 1: 36-50. DOI: 10.3844 /aassg. 2004, 36.50 .

Gurbuz, A.O. and A. Aybars, 2010, The Impact of Foreign Ownership on firm performance, Evidence from an Emerging market. Am. J. Econ. Bus. Admin., $\quad 2: \quad 350-359$. $\quad$ DOI 10.3844/agebasp.2010.350.359

IMF, 2004. Guidelines for Foreign Exchange Reserve Management. 1st Edn., International Monetary Fund, Washington, D.C., ISBN 1589062604, pp: 21.

Ismail, Z., A. Yahya and A. Shabri, 2009. Forecasting gold prices using multiple linear regression method. Am. J. Applied Sci., 6: 1509-1514. DOI 10.3844/ajassp.2009.1509.1514

Umar, A. and H. Soliu, 2008. The Foreign Exchange Rates in Nigeria: Convergence or Divergence.

Yazdani, S. and S. Shaari, 2009. The impact of macroeconomic indicators on agricultural trade balance of Iran. Am. J. Applied Sci., 6: 1473-1477. DOI: 10.3844 /aassp. 2009. 1473.1477 